\title{
Moving From Crisis Reaction to Crisis Response: A Six-Point Non-Violent Alternative to the Bombing Campaign
}

\author{
David Dyck
}

\begin{abstract}
In this paper, the author argues that NATO's decision to bomb Yugoslavia was and is short-sighted. Citing a lack of historical awareness on the part of Western decision makers, he relies heavily on the work of psychodynamics theorist Joseph Montoille in proposing that a better understanding of "the mind of Serbia" would lead us to recognize the folly of our strategy. More specifically, the author contends that our bombing is but part of a cycle that is bound to spawn new rounds of aggression. The author also articulates six key components of an alternative approach. Here, he attempts to address the question of how we might usenon-violent means toprevent the loss of life in the short term and, at the same time, begin the task of building a sustainable, long-term peace.
\end{abstract}

\section{Résumé}

Dans cet article, l'auteur présente une argumentation selon laquelle la décision del'OTAN de bombarder la Yougoslavie fut, et reste, une décision à courte oue. Citant en exemple le manque patent de conscience historique des décideurs occidentaux, il s'appuie sur les travaux du théoricien de la psychodynamique Joseph Montville pour suggérer qu'une meilleure compréhension de l'esprit serbe nous menerait d comprendre la complète ineptie de notre stratégie. Plus spécifiquement, l'auteur démontrequece bombardement n'est rien d'autre qu'un moment à l'intérieur d'un cycle qui entraînera irrémédiablement une nouvelle spirale d'agressions. L'auteur articule

David Dyck is a M.A. candidate in conflict resolution studies at Eastern Mennonite University's Conflict Transformation Program in Harrisonburg, Virginia. He is currently employed as the Project Coordinator for Circles of Support and Accountability (CSA) in Winnipeg, Manitoba. aussi les six elements d'une approche alternative du probleme. Il s'efforce icide répondred la question suivante: comment arriver a utiliser des moyens non-violents pour préronir les pertes de vie d court terme, et, dans lemême mouvement, comment amorcer la tâche de reconstruction à long terme d'une paix viable?

\section{Introduction}

There are many reasons to question our nation's participation in the NATO-led bombing campaign against Yugoslavia. Despite the rhetoric to the contrary, there were and are other options that make more sense. Beyond the many serious moral questions that can and should be raised regarding our reacting to violence with much more massive amounts of violence, it is clear that our response has also been strategically ineffective. At the time of this writing, some 800,000 refugees have been forced out of Kosovo, and many will never return to homes that are now destroyed. While we do not have exact figures, it is also clear that thousands of civilians and military personnel have been killed in both Serbia and Kosovo, the majority by NATO bombs (Faimess \& Accuracy in Reporting List Serve, 1999).

At the same time, the reasoning that suggests it is always our obligation to allow another "sovereign nation" to do as it pleases within its borders is also disturbing. Surely there is something wecan doother than either washing our hands of moral responsibility through legalism, or wading in as the violent arbiter.

\section{Understanding the Mind of Serbia}

Shortly after the bombing began, Canadian newspapers carried stories about protests against NATO's actions by Canadians of Serbian origin and their supporters. The protesters vented their outrage at the thought of their tax dollars being used to bomb relatives and friends in their home country, and challenged the Westemmedia's portrayal of their people as wantonly aggressive.

Some of their signs and placards were particularly memorable. One of them I recall read: "Hitler-1939, Clinton-1999," and juxtaposed the profiles of the two leaders. Another stated "NAZI-1939, NATO-1999," complete with a version of theNATOlogo, altered slightly toclosely resemble the swastika which appeared on the other side of the placard.

For those to whom such signs make no sense, a window of understanding may be available in the analysis of Joseph Montville, a peace-building theorist and psychologist whose paper"Reconciliation as Realpolitik" contains an excellent section on the situation in Kosovo. Penned prior to current explosiveevents, Montville's words now appear chillingly prophetic. The author reaches a level of analysis much deeper than that of current media sound bites. In a section entitled "Understanding the Mind of Serbia," Montville writes:

On June 28, 1989, Milosevic returned to Kosovo to celebrate the 600th anniversary of Serbia's national day which, ironically, marks the defeat of Serb forces by the Ottoman army at the Battle of Kosovo ... "Six centuries ago," Milosevic said, "Serbia defended itself on Kosovo, but it also defended Europe. She found herself on the ramparts for the defense of European culture, religion, and European society as a whole." The Serbian epic poem declares, "Whoever is a Serb and of Serbian blood and comes not to fight at Kosovo ... Let nothing grow from his hand ... until his name is extinguished forever." Thus Kosovo represents for modern Serbs not only the signature event in the establishment of national identity, but also a gift for which Europe shows no gratitude.

Psychologically, there is a direct link between the pro-Nazi Croatian Ustashe 
genocide which killed hundreds of thousands of Serbs during World War II, and the loss at Kosovo, five centuries earlier. In each case, the Serbs perceived Europe as indifferent to their sacrifices. And each case nourished the profound sense of victimhood which tells Serbs that the world cares nothing about their well-being, sacrifices, and losses.

Thus, even as piecemeal deals are worked out by international negotiators between Serbia and its enemies in the current Yugoslav tragedy, the "Kosovo complex" retains the power to explode into a much more dangerous Balkan war... Any strategy which aims to resolve the Balkan conflict once and for all, must, ironically, focus on aggressive and, yes, genocidal Serbia's potverful sense of historic victimhood. To neglect it is to keep the time bomb ticking. (Emphasis mine, Montville, 12-14, , unpublished paper - see bibliography.)

Indeed, the time-bomb appears to have exploded. For many of us, the links that someSerbian-Canadian protesters have been making between NATO's actions and that of Nazi Germany seem, at best, "stretching" things considerably and, at worst, downright ridiculous. Montville's interpretation, however, suggests that such responses may be less outrageous than we might initially be inclined to think. For he shows us that they are not, firstly, about rational analysis but about profound psychological, spiritual, and emotional woundedness related to very real and overwhelming historic experiences of injustice and deep trauma. This is precisely why the author concludes that attempts to deal with these situations through a heavy reliance on rational dialogue, boundary shifting, and the threat of force will only exacerbate the problem.

\section{Six Practical Alternative \\ Responses to a Complex, \\ Long-Term Problem}

So, what can be done in response to a situation which is apparently much more complicated than we have been led to believe? I would like to suggest a number of alternatives to the course we have pursued thus far.

\section{1) In an on-going way, we must provide better training for diplomats in effective listening skills and in understanding the historical context of conflict.}

Montville suggests that government diplomats must be trained to better understand the dynamics of historical victimization if they are to serve meaningfully in the various roles of peacebuilding. More specifically, the author suggests that government representatives must become better skilled in the arts of listening, offering acknowledgement and, where appropriate, reparation. Nations and ethnic groups mustbe helped to name and grieve their losses. The first step towards allowing this to happen involves acknowledging that something happened - that, for example, Serbia has repeatedly been the victim of horrific aggression and that the West has, in the not-so-distant past, stood by and allowed it to happen (Montville).

\section{2) In an on-going way, we must develop a better understanding of the role of perceived injustice and of the symbolic dimensions of conflict.}

In addition, political leaders and negotiators must come to takemore seriously the critical role that symbol, ritual, and narrative must play in this healing process. As suggested earlier, complex conflict is very often not primarily about that which it may initially appear to be about. (For example, "How much square footage of Kosovo would satisfy Milosevic?" is the wrong question.) Indeed, some peace-building practitioners have suggested that violence such as that which is taking place in Kosovo is rooted in fundamentally differing worldviews-different stories about the very nature of the universe (Docherty 1996).

While we will probably never change the reality of this diversity (and would notwant to!), conflict resolution theorist Jayne Docherty has suggested that a deeper order of transformation is accessible through giving more attention to themyths, legends, and symbols which shape a people (Docherty 1996). With Montville and others, she encourages negotiators to learn how to tap into and give greater respect to these "soft" elements, to finally understand that a party's need for recognition often outweighs its concern for the "hard" material questions which usually receive the bulk of diplomatic attention (Montville; Volcan 1990).

On the simplest of levels, this analysis resonates with my experience as a mediator in the victim-offender mediation room. Here, victims are usually more concerned that the offender understand their experience and take meaningful, often symbolic, steps toward responsibility, than they are about financial compensation for losses. To this end, Howard Zehr has recently suggested that "most violence, perhaps much crime, originates from perceived harms and injustices that are not adequately addressed" (Zehr 1999). Is the same not likely true of the criminal acts of Serbia and Milosevic in Kosovo? If so, do we not simply continue to feed the cycle with our own acts of violence against Yugoslavia? So what should we do right now?

\section{3) In the immediate term, we should stop the bombing and offer our "contrition."}

Discussing the Israeli-Palestinian conflict, Cynthia Ozickhas suggested that:

What is required ... as an element of realpolitik is an understanding that mutual contrition, even more than the resolution of issues of acreage and border patrols, must be the next step in the peace process ... Hard-headed politicos will no doubt scoff at the notion of mutual contrition as a way of enhancing the negotiations. They will think it too soft a proposal, smacking of useless high ground, unserious, devoid of pragmatism. But no way ... can be more serious, more allied to truth-telling, more effective and more profoundly practical (Montville, 26).

To this end, in the immediate situation, NATO could provide a powerful example and potentially set us all on the long road to recovery and peace by acknowledging that we have made a mis- 
take in using violent threats and acts as a means of pursuing peace. We could immediately cease our violence and, instead, offer remorse for the many people we have killed in our misguided bombing campaign. We could extend a particular offer of remorse for the many innocent civilians we have maimed or killed and for the untold suffering that will yet result from the massive destruction we have rained on Yugoslavia. We could offer full and meaningful compensation to Yugoslavia for losses inflicted and enact symbolic, public displays of repentance and cleansing. Relief and development agencies of all kinds could show leadership in this regard by choosing to send shipments of practical aid to the suffering people of both Kosovo and Serbia.

But doesn't Yugoslavian capitulation to all our demands, which we are assured is imminent, vindicate our aggressive approach? Would not a decision to cease bombing and apologize, then, have been strategically counterproductive when Milosevic is about to finally acknowledge the error of his ways?

The media watchdog organization, Fairness and Accuracy in Reporting, tells a different story. They suggest that it is NATO, and not Belgrade, which significantly altered its demands in the last ten weeks of the bombing campaign. Furthermore, they contend that the Western media's portrayal of Serbia's "surrender" in the face of our "effective" bombing represents nothing more than our attempt to extricate ourselves from a horrendous situation of our own making without acknowledging our folly. They argue that the bombing has, in fact, accomplished very little and that halting it, therefore, would have threatened very little while bringing an end to much unnecessary carnage (Fairness and Accuracy in Reporting ListServe 1999).

Regardless of how one assesses these differing viewpoints, one thing remains clear: any "peace" which is built on the foundation of remorselessly pounding a small nation for $\mathbf{7 5}$ days is sure to be fragile in the long-term. In this sense then, even at this late stage, an honest acknowledgement of our poor judge- ment in ever commencing such a campaign would serve ourlong-range interests better than any deals we have settled on through continued aggression and elaborate attempts to justify our actions.

\section{4) In the immediate term, we must stand by those who suffer oppression in non-violent ways.}

But what about the people of Kosovo? Doesn't abandoning the bombing mean abandoning the Kosovar Albanian people to the Serbian campaign of ethnic cleansing? It need not mean that. It could mean, rather, that at the same time as we offer remorse for our choice to resort to war, we re-state our resolve to stand by suffering people everywhere.

In the current situation of Yugoslavia, this mightentail gathering together a force of individuals who are trained in the skills of non-violent intervention and accompaniment. This implies our risking our own lives to stand by those who are at risk of losing theirs. Organizations such as Peace Brigades International, among others from the NGO community, could hold emergency training in this regard. While this response may seem a little unrealistic to many, theorist Gene Sharpe and others have written persuasively on the past and potential future effectiveness of non-violent, civilian-based defense forces (Sharp 1990; Wink 1992). A similarstand-by contingent could be trained and called upon by the world community in especially acute crisis situations, such as the one we are now facing in Kosovo.

\section{5) In the long-term, we must invest in peace before the advent of crises.}

While it might be difficult to instantly mobilize the kind of force Sharp describes, we would do well to remember that the seeds of the current crisis were sown long ago in our collective neglect to prepare for peace. Joseph Campbell, of the Mediation Network in Northern Ireland, remarked in a speech delivered in Harrisonburg, Virginia, in the fall of 1997, that if we invested even a tenth of the resources we currently devote to preparing for and waging war in preparing for and waging peace, we would quickly see a remarkable downturn in global violence. What if, for example, we spent as much energy training non-violent interventionists/activists, conciliators, and mediators as we do training foot soldiers, military strategists, and creating military hardware? With so many leading Western nations (especially the United Kingdom and the United States) continuing to be so heavily invested in the global arms trade, however, it is admittedly hard to imagine such a turn of events.

\section{6) Putting it all together-we must invest in a "middle-out" strategy of peace-building.}

Finally, beyond the immediate avenues of ceasing ourbombing; offering ameaningful apology and rebuilding assistance; and training and deploying people skilled in conflict analysis, worldview dialogue, and non-violent intervention, I would also like to suggest John Paul Lederach's long-term strategy of relational investment (Lederach 1997). Lederach has written persuasively on the importance of responding in the immediate context in such a way as to contribute to the long-term realization of our vision for a peaceful world. He suggests that we resist the urge of "knee-jerk" reactions to situations like the one in Kosovo, and instead begin to think in terms of generational goals. That is, we must ask what can be done now in Kosovo/Yugoslavia, so that the grandchildren and great-grandchildren of thecurrent generation are more likely to be able to live in peace. We must become "crisis responsive" rather than "crisis reactive" (Lederach 1997).

To this end, Lederach calls for a shift from "top-down" approaches to peacebuilding, wherein we focus the bulk of our energy at the level of elite leadership (i.e., the Milosevices and top aides at Rambuillet), to a "middle-out" approach, wherein individuals who have connections to both the grass-roots and the elite levels become the focus. These persons are then given training in the skills and concepts of building a sus- 
12.

tainable peace and, most vitally, are brought together to build relationships with their counterparts from other communities.

Ideally, these would be individuals who can articulate the historic grievances of their communities, but who are motivated to avoid bloodshed and able to truly hear about and understand the experiences of others. Furthermore, it is best to locate those who have cross-cutting ties-people who already have some connections with their counterparts in other communities, and yet retain a large measure of trust and credibility in their own. Having worked extensively in the Basque region of Spain, in Northern Ireland, in Nicaragua and the Philippines, among other tom regions, Lederach contends that such "strategic" people of immense peace-building potential exist in all conflicted communities (Lederach 1997).

\section{Conclusion}

As I think about the current problems of Kosovo,lrecalla young Serbian woman with whom I travelled and worked in January of 1995. A young doctor in training (she was 21 years old at the time), Sladja had lived in Belgrade during the war of the early 1990s and had endured the suffering that comes with the unexpected death ofloved ones. One of the most important things she helped me to re-understand was that things are inevitably more complex than they seem on the surface. More specifically, as a Serbian who did not agree with the actions of her government but who also felt resentment and anger at the Westfor our one-dimensional portrayal of her country, she showed me that there were thinking, well-motivated Serbians who, for good reasons, feel misunderstood and alone. Indeed, Montville's description of a Serbian sense of "awesome loneliness" fits well with my memories of Sladja' s attempts to describe the way she and her compatriots felt (Montville, 14).

In conclusion, if we hope to contribute to the establishment of long-term peace in places like Kosovo, we must learn to build bridges to people like Sladja, rather than bomb bridges in the

Refuge, VoL 18, No.3 (August 1999) hopes of a "quick-fix" solution. This will mean foregoing the immediate, if somewhat myopic, satisfaction of" doing something to the bad guys" in favour of an approach that requires self-discipline, reflection, and sustained commitment.

While such commitment is admittedlya "tough sell," I would argue, with Lederach and others, that this is a large part of what is required for the world community to respond more effectively to humanitarian crises such as the one we are currently facing in Kosovo (Lederach 1997; Dugan 1996). The global humanitarian relief and development community would therefore do well to consider how we might help to bring about such an overall change in understanding and approach .••

\section{References}

Docherty, Jayne S. 1996. "The Stewardship Metaphor in Forest Resource Management Conflicts: A Common Language Does Not Guarantee Consensus." In Conflict Analysis and Resolution: Challenges for the Times, edited by Daniel McFarland. Fairfax, Virginia: The Institute for Conflict Analysis and Resolution.

Dugan, Maire. 1996. "A Nested Theory of Conflict." A Leadership Journal: Women in Leadership-Sharing the Vision 1 (July, 1996): 9-20.

Fairness \& Accuracy in Reporting List Serve: Media Analysis, Critiques, and News Reports. 1999 (June 4). They Call This Victory? Bombing "Success" Must Be Weighed Against
Human Cost, Missed Chances for Peace. Congers, New York: Error! Hyperlink reference not valid. international! yugoslavia.htm1.>>

Lederach, John Pau1. 1997. Building Peace: Sustainable Reconciliation in Divided Societies. Washington, DC: Endowment of the United States Institute for Peace.

Montville, Joseph V. "Reconciliation as Realpolitik." This paper is a working draft currently being prepared for publication as a book chapter. Dr. Montville currently works as the Director of the Preventive Diplomacy Program at the Centre for Strategic and International Studies which is located in Washington, DC. Please see the CSIS.org webpage for more information on Dr. Montville and a description of the program.

Ozick, Cynthia. 1994. "Mutual Sorrow, Mutual Gain." The New York Times, March 2, 1994, A15 (as quoted in Joseph V. Montville's "The Psychological Burdens of History").

Sharp, Gene. 1990. Civilian-Based Defence: A Post-Military Weapons System. Princeton, NJ: Princeton University Press.

Volcan, VamikD.1990. "AnOverviewofPsychological Concepts Pertinent to Interethnic and/ or International Relationships." In The Psychodynamics of International Relationships: Theories and Concepts, Vo1.1,edited by VamikD. Volcan, Joseph V. Montville, and Julius A. Demetrios. Lexington, MA: Lexington Books.

Wink, Walter. 1992. Engaging the Powers: Discernment and Resistance in a World ofDomination. Minneapolis, MN: Augsburg Fortress.

Zehr, Howard. Correspondence with the author via email in March of 1999. o

\section{Refuge}

\section{Canada's Periodical on Refugees}

\section{Published six times a year by the Centre for Refugee Studies,} York University, Toronto.

Available from:

$$
\begin{gathered}
\text { Centre for Refugee Studies, York University } \\
\text { Suite 333, York Lanes, } 4700 \text { Keele St. } \\
\text { Toronto ON M3J 1P3 } \\
\text { Fax: (416) 736-5837 - Email: refuge@yorku.ca } \\
\text { http://www.yorku.ca/research/crs }
\end{gathered}
$$

